\title{
THE CONCENTRATION OF UNCONJUGATED OESTRONE, OESTRADIOL-17 $\alpha$ AND OESTRADIOL-17 $\beta$ IN THE MATERNAL PLASMA OF THE PREGNANT EWE IN RELATION TO THE INITIATION OF PARTURITION AND LACTATION*
}

\author{
H. A. ROBERTSON AND T. G. SMEATON $\dagger$ \\ Reproductive Physiology Section, Animal Research Institute, \\ Ottawa, Canada
}

(Received 8th November 1972)

\begin{abstract}
Summary. The concentration of unconjugated oestrone, oestradiol-17 $\alpha$ and oestradiol- $17 \beta$ has been measured in the maternal jugular venous plasma of pregnant sheep every $6 \mathrm{hr}$ over the period $108 \mathrm{hr}$ before to $72 \mathrm{hr}$ after parturition. Measurable levels of each oestrogen were present $108 \mathrm{hr}$ before parturition and by about $40 \mathrm{hr}$, the concentration began to increase markedly. Levels of 200 to $350 \mathrm{pg} / \mathrm{ml}$ for oestrone and 100 to $150 \mathrm{pg} / \mathrm{ml}$ for oestradiol- $17 \alpha$ and for oestradiol-17 $\beta$ were found just before parturition. At $12 \mathrm{hr}$ after parturition, the concentration of oestrone and oestradiol-17 $\beta$ had fallen to $<15 \mathrm{pg} / \mathrm{ml}$. Levels of oestradiol$17 \alpha$ remained elevated for a longer period after parturition and did not fall to $<35 \mathrm{pg} / \mathrm{ml}$ until 48 to $60 \mathrm{hr}$ after parturition.
\end{abstract}

\section{INTRODUGTION}

The work of Liggins, Kennedy \& Holm (1967) and Liggins \& Kennedy (1968) has aroused considerable interest in the rôle of the steroid hormones of fetal and/or placental origin in the initiation of parturition. In the pregnant sheep, Findlay \& Cox (1970) found high levels of oestrogen sulphates in the fetal plasma while Challis (1971) and Challis, Harrison \& Heap (1971) found that, in this species, a sharp rise in the concentration of total unconjugated oestrogens occurred just before parturition. In the maternal plasma of the goat during the last few days of pregnancy, Challis \& Linzell (1971) found a rise in the concentration of the total unconjugated oestrogens while Thorburn, Nicol, Bassett, Shutt \& Cox (1972) found a rise in unconjugated oestrone and oestradiol-17 $\alpha$ which was paralleled by a rise in the secretion of oestrogens from the conceptus.

The rise in plasma oestrogens in the pregnant sheep before parturition has been investigated in detail, using a method which has been developed to measure the individual unconjugated oestrogens in plasma (Robertson, Smeaton \&

* Contribution No. 474 from the Animal Research Institute, Ottawa.

$\dagger$ Present address: Department of Obstetrics and Gynaecology, University of Adelaide, Australia. 
Durnford, 1972). The report documents the changes in the maternal jugular venous plasma concentration of unconjugated oestrone, oestradiol-17 $\alpha$ and oestradiol-17 $\beta$ in eight sheep over the period $108 \mathrm{hr}$ before to $72 \mathrm{hr}$ after normal parturition and the initiation of lactation.

\section{MATERIALS AND METHODS}

\section{Animals}

Eight Western ewes were mated by a ram fitted with a marking harness and the time of mating was recorded. Throughout gestation, the ewes were housed in individual pens. Over the period beginning 6 days before the estimated time of parturition, the ewes were watched continuously, with the exception of the period from 02.00 to 08.00 hours, and blood sampling was commenced. Two of the eight ewes lambed within this 6 -hr period.

\section{Blood sampling}

Blood samples $(10 \mathrm{ml})$ were collected by needle puncture into heparinized tubes every $6 \mathrm{hr}$ at $02.00,08.00,14.00$ and 20.00 hours and the sampling was continued until $72 \mathrm{hr}$ post partum. Immediately after collection, the tubes were chilled in iced water, centrifuged and $2 \cdot 5-\mathrm{ml}$ aliquots of plasma were transferred into glass vials which were sealed and kept frozen at $-20^{\circ} \mathrm{C}$ until used for assay.

The time of collection of all samples was subsequently standardized, taking the time of parturition as $0 \mathrm{hr}$. As it was impracticable to carry out estimations of oestrone, oestradiol-17 $\alpha$ and oestradiol-17 $\beta$ on all plasma samples collected from each animal, the ewes were divided into two groups depending upon whether they had a single lamb (four ewes) or twins (four ewes) and pooled samples were made for each 6-hr period within the two groups. Thus, each pooled sample contained aliquots from four ewes. In order to obtain an estimate of the between-animal variation and to determine the effect, if any, of the sex of the fetus, individual estimates were carried out on the plasma samples taken from each animal during the sampling period 12 to $7 \mathrm{hr}$ before parturition.

\section{Oestrogen determination}

Unconjugated oestrone, oestradiol-17 $\alpha$ and oestradiol-17 $\beta$ were measured by the method of Robertson et al. (1972) using $1 \mathrm{ml}$ plasma.

Oestrone and oestradiol-17 $\beta$ were estimated from a standard curve for oestradiol-17 $\beta$ while oestradiol-17 $\alpha$ was estimated from one for oestradiol-17 $\alpha$.

The sensitivity of the method has been estimated to be $11 \mathrm{pg}$ for oestrone, $13 \mathrm{pg}$ for oestradiol-17 $\beta$ and $34 \mathrm{pg}$ for oestradiol-17 $\alpha$. All assays were carried out in duplicate and the values obtained were corrected for procedural losses.

\section{RESULTS}

Table 1 shows the time of onset of parturition, the sex of the lamb(s) and the time interval in hours between the last pre-partum sample and parturition for each of the ewes within the two groups. 
Table 1. Gestation length, sex and weight of lambs born to 'single lamb' and 'twin lamb' groups of ewes

\begin{tabular}{|c|c|c|c|c|c|}
\hline Ewes & $\begin{array}{l}\text { Sex of } \\
\operatorname{lamb(s)}\end{array}$ & $\begin{array}{c}\text { Weight of } \\
\operatorname{lamb(s)} \\
(\mathrm{kg})\end{array}$ & $\begin{array}{c}\text { Time of lambing } \\
(\text { houts })\end{array}$ & $\begin{array}{l}\text { Time interval } \\
\text { (hr) between } \\
\text { pre-partum } \\
\text { sample and } \\
\text { parturition }\end{array}$ & $\begin{array}{c}\text { Gestation } \\
\text { length } \\
\text { (days) }\end{array}$ \\
\hline $\begin{array}{l}\text { 'Single lamb' group } \\
\text { B21 } \\
\text { R35 } \\
\text { Y39 } \\
\text { Y40 }\end{array}$ & $\begin{array}{l}\mathbf{M} \\
\mathbf{M} \\
\mathbf{F} \\
\mathbf{M}\end{array}$ & $\begin{array}{l}3 \cdot 3 \\
5 \cdot 1 \\
5 \cdot 8 \\
5 \cdot 9\end{array}$ & $\begin{array}{c}02.00 \text { to } 08.00 \\
13.45 \\
15.30 \\
02.00 \text { to } 08.00\end{array}$ & $\begin{array}{r}0 \text { to } 6.00 \\
5.75 \\
1.50 \\
0 \text { to } 6.00\end{array}$ & $\begin{array}{l}144 \\
148 \\
148 \\
148\end{array}$ \\
\hline $\begin{array}{l}\text { 'Twin lamb' group } \\
\text { B34 } \\
\text { G34 } \\
\text { G34 } \\
\text { R36 }\end{array}$ & $\begin{array}{l}\mathbf{F}, \mathbf{F} \\
\mathbf{M}, \mathbf{M} \\
\mathbf{M}, \mathbf{M} \\
\mathbf{M , F}\end{array}$ & $\begin{array}{l}3 \cdot 3,2 \cdot 9 \\
3 \cdot 0,3 \cdot 3 \\
2 \cdot 8,2 \cdot 3 \\
2 \cdot 5,2 \cdot 3\end{array}$ & $\begin{array}{l}15.30 \\
19.30 \\
13.00 \\
10.45\end{array}$ & $\begin{array}{l}1 \cdot 50 \\
5 \cdot 50 \\
5 \cdot 00 \\
2 \cdot 75\end{array}$ & $\begin{array}{l}149 \\
145 \\
144 \\
145\end{array}$ \\
\hline
\end{tabular}

There could be a difference of up to $6 \mathrm{hr}$ between the time of the last sample taken and the time of parturition because blood samples were taken only every $6 \mathrm{hr}$ at fixed times of the day.

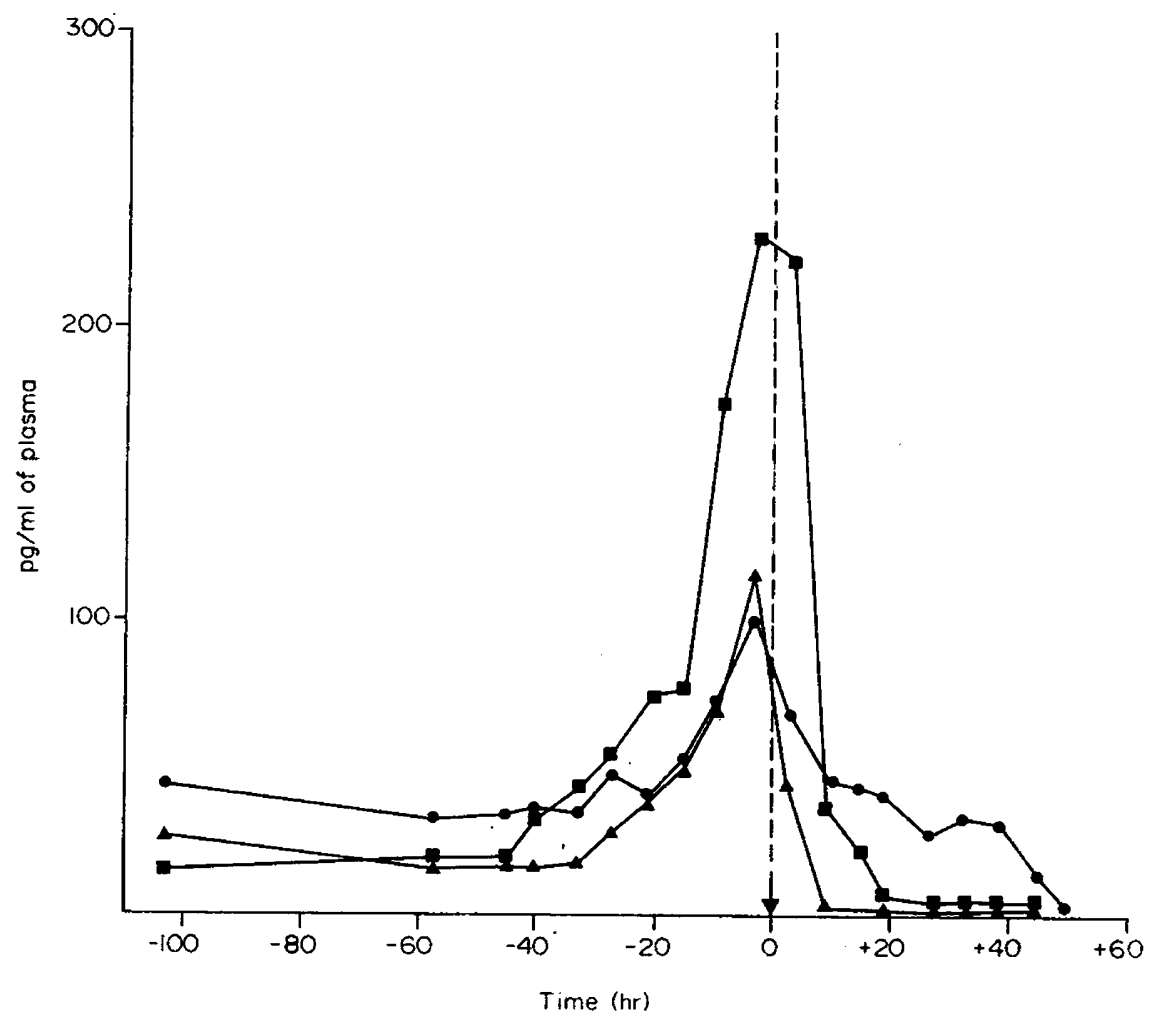

TEXT-FIc. 1. Changes in the maternal jugular venous plasma concentration of unconjugated oestrone $(\square)$, oestradiol-17 $\alpha(\bullet)$ and oestradiol-17 $\beta(\Delta)$ in relation to the time of parturition $(0 \mathrm{hr})$, in ewes $(n=4)$ carrying a single lamb. 
It should be noted that the group of ewes which had twin lambs was equally weighted as far as the sex of the lambs was concerned, whereas the group having single lambs was heavily weighted in favour of male lambs.

\section{Plasma oestrogen values}

The changes in the concentration of unconjugated oestrone, oestradiol-17 $\alpha$ and oestradiol- $17 \beta$ in the pooled plasma samples from each group, over the period $108 \mathrm{hr}$ before, to $60 \mathrm{hr}$ after, parturition are shown in Text-figs 1 and 2 .

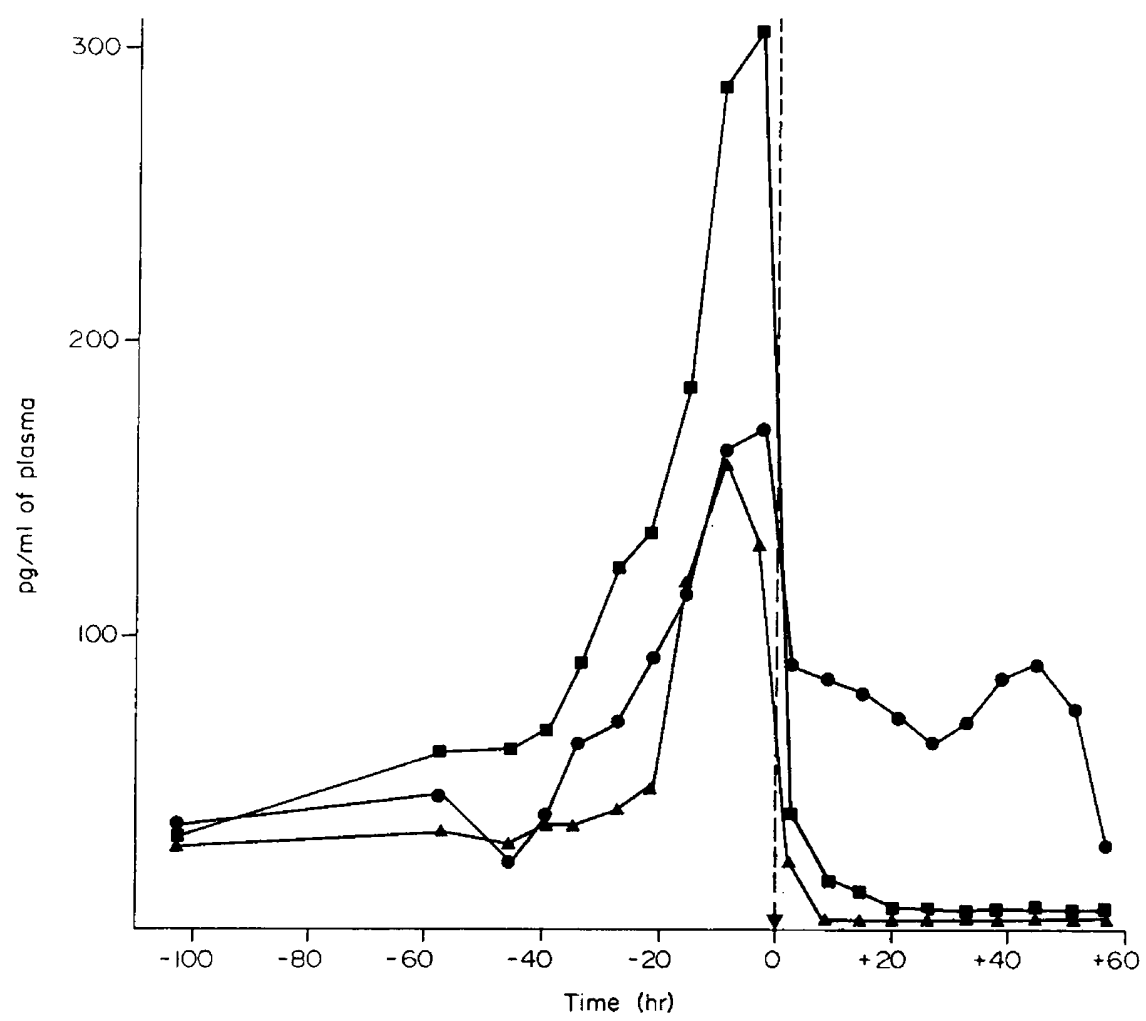

TExT-FIG. 2. Changes in the maternal jugular venous plasma concentration of unconjugated oestrone $(\square)$, oestradiol-17 $\alpha(\bullet)$ and oestradiol-17 $\beta$ ( $\Delta)$ in relation to the time of parturition $(0 \mathrm{hr})$, in ewes $(n=4)$ carrying twin lambs.

Measurable concentrations of unconjugated oestrone, oestradiol-17 $\alpha$ and oestradiol-17 $\beta$ could be detected $108 \mathrm{hr}$ before parturition. In both groups, a rapid increase in the concentration of all the oestrogens was discernible, commencing about $40 \mathrm{hr}$ before parturition and reaching a maximum around the time of parturition. At peak concentration, the mean levels of oestradiol-17 $\alpha$ and of oestradiol- $17 \beta$ were very similar and lay within the range of 100 to 150 $\mathrm{pg} / \mathrm{ml}$, whereas the concentration of oestrone $(225$ to $300 \mathrm{pg} / \mathrm{ml}$ ) was approximately double that of the individual oestradiols. After parturition, there was a rapid fall in the concentration of unconjugated oestrone and oestradiol-17 $\beta$, to 
$<15 \mathrm{pg} / \mathrm{ml}$ by $10 \mathrm{hr}$ post partum. Compared to oestrone and oestradiol-17 $\beta$, the decline in the concentration of oestradiol-17 $\alpha$ was less rapid. Nevertheless, the concentration had dropped to $<35 \mathrm{pg} / \mathrm{ml}$ by $45 \mathrm{hr}$ post partum in the 'single lamb' group and by $60 \mathrm{hr}$ post partum in the 'twin lamb' group. This apparently anomalous behaviour of oestradiol-17 $\alpha$ will be discussed later.

Table 2 presents the oestrogen concentrations in the plasma samples of individual ewes from each group taken during the period 12 to $7 \mathrm{hr}$ before

Table 2. The concentration of unconjugated oestrogens in individual jugular venous plasma samples of pregnant ewes taken 12 to $7 \mathrm{hr}$ before parturition

\begin{tabular}{|c|c|c|c|c|}
\hline \multirow{2}{*}{ Ewes } & \multirow{2}{*}{ Sex of lamb } & \multicolumn{3}{|c|}{$\begin{array}{l}\text { Concentration of oestrogen }(\mathrm{pg} / \mathrm{ml} \mathrm{l}) \\
(\text { duplicate samples and mean })\end{array}$} \\
\hline & & Oestrone & Oestradiol-17 1 & Oestradiol $-17 \beta$ \\
\hline $\begin{array}{l}\text { ‘Single lamb' group } \\
\text { B21 }\end{array}$ & $\mathbf{M}$ & $\begin{array}{l}275 \\
258\end{array} 267$ & $\underset{110}{98} 104$ & $\begin{array}{ll}81 & 85 \\
89 & 85\end{array}$ \\
\hline $\mathrm{R} 35$ & $\mathbf{M}$ & $\begin{array}{l}133 \\
130\end{array}$ & $\begin{array}{ll}71 & 72 \\
74 & 72\end{array}$ & $\begin{array}{ll}56 & 56 \\
55\end{array} 56$ \\
\hline Y39 & $\mathrm{F}$ & $\begin{array}{l}167 \\
161\end{array}$ & $\begin{array}{ll}76 & 76 \\
75 & \end{array}$ & $\begin{array}{ll}72 & 78 \\
88 & 78\end{array}$ \\
\hline $\mathrm{Y} 40$ & $\mathbf{M}$ & $\begin{array}{r}100 \\
91\end{array} 96$ & $\begin{array}{ll}77 & 70 \\
62 & \end{array}$ & $\begin{array}{ll}86 & 83 \\
79 & \end{array}$ \\
\hline $\begin{array}{l}\text { Group mean } \pm \text { S.D. } \\
\text { Estimate on pooled } \\
\text { sample (Text-fig. 1) }\end{array}$ & & $\begin{array}{l}165 \pm 74 \\
169\end{array}$ & $\frac{80 \pm 16}{73}$ & $\begin{array}{l}76 \pm 13 \\
71\end{array}$ \\
\hline $\begin{array}{l}\text { 'Twin lamb' group } \\
\text { B34 }\end{array}$ & $\mathbf{F}, \mathbf{F}$ & $\begin{array}{l}313 \\
338\end{array} 326$ & $\begin{array}{l}180 \\
173\end{array} 176$ & $\begin{array}{r}110 \\
90\end{array} 100$ \\
\hline G34 & $\mathbf{M}, \mathbf{M}$ & $\begin{array}{l}514 \\
469\end{array} 492$ & $\begin{array}{l}217219 \\
221\end{array}$ & $\begin{array}{l}137142 \\
147\end{array}$ \\
\hline G35 & $\mathrm{M}, \mathrm{F}$ & $\begin{array}{l}140 \\
115\end{array}$ & $\begin{array}{ll}88 & 80\end{array}$ & $\begin{array}{r}103 \\
74\end{array} 87$ \\
\hline R36 & $\mathrm{M}, \mathrm{F}$ & 230248 & $\begin{array}{l}183 \\
183\end{array}$ & $\begin{array}{l}214193 \\
171\end{array}$ \\
\hline $\begin{array}{l}\text { Group mean } \pm \text { S.D. } \\
\text { Estimate on pooled } \\
\text { sample (Text-fig. } 2 \text { ) }\end{array}$ & & $\begin{array}{l}298 \pm 154 \\
294\end{array}$ & $\begin{array}{l}165 \pm 59 \\
168\end{array}$ & $131 \pm 48$ \\
\hline
\end{tabular}

parturition. Considerable variation existed between and within the animals of each group.

If the concentration of individual oestrogens is compared between the groups, the concentration of oestradiol- $17 \beta$ is seen to be marginally significantly higher $(P<0.05)$ in the 'twin lamb' group. The between-group differences for oestrone and oestradiol-17 $\alpha$ are not significant.

The effect of sex, weight and number of the fetuses

It is not possible from the data available in Table 2 to determine whether plasma unconjugated oestrogen levels are influenced by the number of conceptuses or the sex of the fetus(es). 


\section{DISCUSSION}

It is clear from the results that a dramatic increase in the concentration of unconjugated oestrone, oestradiol- $17 \alpha$ and oestradiol- $17 \beta$ occurs in the jugular venous plasma of the pregnant ewe beginning at about $40 \mathrm{hr}$ before parturition and reaching a peak at parturition. The concentrations of oestradiol-17 $\alpha$ and oestradiol-17 $\beta$ are very similar and are approximately half that of the concentration of oestrone. After parturition, the concentrations of oestrone and oestradiol- $17 \beta$ have dropped to $<15 \mathrm{pg} / \mathrm{ml}$ by $10 \mathrm{hr}$ post partum. The drop in the concentration of oestradiol-17 $\alpha$ is not so precipitous, taking approximately $45 \mathrm{hr}$ to reach $<35 \mathrm{pg} / \mathrm{ml}$ in the case of the 'single lamb' group and $60 \mathrm{hr}$ in the case of the 'twin lamb' group.

The data of Challis (1971) on the change in the level of total unconjugated oestrogens, of Thorburn et al. (1972) on unconjugated oestradiol-17 $\beta$ and of Bedford, Challis, Harrison \& Heap (1972) on unconjugated oestradiol-17 $\beta$ and oestrone in the blood of the pregnant ewe just before parturition are in agreement with the present findings. Challis, Harrison \& Heap (1971) and Bedford et al. (1972) have demonstrated that the probable source of those unconjugated oestrogens at this time was the conceptus. In the goat, Challis \& Linzell (1971) found higher levels of total unconjugated oestrogens and, as a consequence, were able to demonstrate a gradual rise in plasma oestrogen levels right through pregnancy culminating in a sharper rise over the last week. Thorburn et al. (1972) reported an increase in unconjugated oestrone and oestradiol-17 $\beta$ in the maternal jugular venous plasma of goats over the last 2 days of pregnancy and were able to relate this to an increase in the difference between the uterine arterial and venous concentrations. The sensitivity of the method used in the present investigation precludes testing for the presence, or otherwise, of a steady rise in maternal plasma oestrogen level throughout pregnancy in the ewe. In the cow, Robinson, Baker, Anastassiadis \& Common (1970) reported a marked rise in the concentration of total oestrone (conjugated and unconjugated) during the last 30 to 14 days before parturition while Robertson (1974) found a rise in the concentration of unconjugated oestrone, oestradiol-17 $\alpha$ and oestradiol-17 $\beta$ in the maternal plasma over the last 20 days of pregnancy. In the rat, a sharp rise in the ovarian secretion of oestrogens occurs just before parturition (Yoshinaga, Hawkins \& Stocker, 1969) but in the other species studied, i.e. woman (Roy \& MacKay, 1962) and the guinea-pig (Challis, Heap \& Illingworth, 1971), where a prolonged rise in oestrogen levels during pregnancy was found, it is still uncertain whether this rate of increase accelerates immediately before parturition.

Normally, ewes will ingest the placental membranes at parturition and will imbibe some of the amniotic fluid through licking the lamb. It is possible that the more gradual decline in the level of oestradiol-1 $7 \alpha$ observed after parturition, at a time when the concentrations of oestrone and oestradiol-17 $\beta$ are undetectable, may be due to a steady absorption of this oestrogen or a precursor oestrogen from the ingested membranes. Robertson (1974) did not observe a prolonged elevation in oestradiol-17 $\alpha$ in cows where the placental membranes were not ingested. Challis \& Linzell (1971) specifically refer to the ingestion of 
the shed placental membranes by one of their goats but noted that, $24 \mathrm{hr}$ after parturition, unconjugated oestrogens could not be detected in jugular venous plasma. However, in the method used by these workers for measuring total unconjugated oestrogens, only oestrone or oestradiol-17 $\beta$ was used for the construction of standard curves. It is unlikely that this method would have been sufficiently sensitive to demonstrate a prolonged elevation of oestradiol-17 $\alpha$ because oestradiol- $17 \alpha$ competes poorly with these two oestrogens for antibodybinding sites (approximately $30 \%$ affinity).

The relationship between the maternal plasma levels of cortisol, progesterone, oestrogens and the initiation of parturition has been reviewed by Liggins, Grieves, Kendall \& Knox (1972), Thorburn et al. (1972) and by Bedford et al. (1972).

The relevance of oestrogens to the development of the mammary gland during gestation should be considered. This general area has been reviewed by Cowie (1971) and the general finding from experiments carried out on cows and on goats is that a combination of progesterone and oestrogen would appear to yield the best stimulation in the non-pregnant animal. In the pregnant ewe, it is difficult to postulate a rôle for the oestrogens in mammary growth unless (a) the mammary gland has the ability to concentrate these steroids in the cells, (b) the cells are sensitive to concentrations of oestrogens at levels of $<10 \mathrm{pg} / \mathrm{ml}$ or (c) the influence of oestrogens is only extended during the last 2 days of pregnancy. The precipitous rise in unconjugated oestrogen concentration in the plasma of the ewe would seem to be more closely linked to the initiation of lactogenesis which occurs within less than $72 \mathrm{hr}$ of parturition.

The events occurring in late gestation in the ewe, i.e. a period of preconditioning to an elevated level of progesterone followed by a decrease in progesterone concentration at the time of the oestrogen surge, mimic the conditions which induce behavioural oestrus during the normal oestrous cycle. They may, therefore, explain the phenomenon of post-partum behavioural oestrus which is observed in some ewes at parturition.

\section{ACKNOWLEDGMENTS}

We wish to thank Mr R. Durnford for skilled technical assistance, Dr B. V. Caldwell for the antiserum and Dr D. S. Lane for the $\left[{ }^{3} \mathrm{H}\right]$ oestradiol- $17 \alpha$ used in the above assays. One of us (T.C.S.) was an N.R.C. Postdoctoral Fellow.

\section{REFERENCES}

Bedford, C. A., Challis, J. R. G., Harrison, F. A. \& Heap, R. B. (1972) The rôle of oestrogens and progesterone in the onset of parturition in various species. F. Reprod. Fert. Suppl. 16, 1.

Challis, J. R. G. (1971) Sharp increase in free circulating oestrogens immediately before parturition in sheep. Nature, Lond. 229, 20.

Challis, J. R. G., Harrison, F. A. \& Heap, R. B. (1971) Uterine production of oestrogens and progesterone at parturition in the sheep. $\mathcal{F}$. Reprod. Fert. 25, 306.

Challis, J. R. G., HeaP, R. B. \& Illingworth, D. V. (1971) Concentrations of oestrogen and progesterone in the plasma of non-pregnant, pregnant and lactating guinea-pigs. F. Endocr. 51, 1333.

Challis, J. R. G. \& Linzell, J. L. (1971) The concentration of total unconjugated oestrogens in the plasma of pregnant goats. F. Reprod. Fert. 26, 401.

CowIE, A. T. (1971) Influences of hormones on mammary growth and milk secretion. In: Lactation. Ed. I. R. Falconer. Butterworth, London. 
Findlay, J. K. \& Cox, R. I. (1970) Oestrogens in the plasma of the sheep foetus. F. Endocr. 46, 281.

Liggrns, G. C., Grieves, S. A., Kendall, J. Z. \& Knox, B. S. (1972) The physiological rôles of progesterone, oestradiol-17 $\beta$ and prostaglandin $\mathrm{F}_{2 \alpha}$ in the control of ovine parturition. F. Reprod. Fert. Suppl. 16, 85.

LigGins, G. G. \& KeNNEDy, P. C. (1968) Effects of electrocoagulation of the foetal lamb hypophysis on growth and development. F. Endocr. 40, 371.

Liggins, G. C., KenNedy, P. C. \& Holm, L. W. (1967) Failure of initiation of parturition after electrocoagulation of the pituitary of the foetal lamb. Am. F. Obstet. Gynec. 98, 1080.

Robertson, H. A. (1974) Changes in the concentration of unconjugated oestrone, oestradiol-17 $\alpha$ and oestradiol-17 $\beta$ in the maternal plasma of the pregnant cow in relation to the initiation of parturition and lactation. F. Reprod. Fert. 36, 1.

Robertson, H. A., Smeaton, T. C. \& Durnford, R. (1972) A method for the extraction, separation and estimation of unconjugated estrone, estradiol-17 $\alpha$ and estradiol-17 $\beta$ in plasma. Steroids, 20,651 .

Robinson, R., Baker, R. D., Anastassiadis, P. A. \& Common, R. H. (1970) Estrone concentrations in the peripheral blood of pregnant cows. F. Dairy Sci. 53, 1592.

RoY, E. J. \& MACKAY, R. (1962) The concentration of oestrogen in blood during pregnancy. F. Obstet. Gynaec. Br. Commonw. 69, 13.

Thorburn, G. D., Nicol, D. H., Bassett, J. M., Shutt, D. A. \& Cox, R. I. (1972) Parturition in the goat and sheep: changes in corticosteroids, progesterone, oestrogens and prostaglandin F. $\mathcal{F}$. Reprod. Fert. Suppl. 16, 61.

Yoshinaga, K., Hawkins, R. A. \& Stocker, J. F. (1969) Estrogen secretion by the rat ovary in vivo during the estrous cycle and pregnancy. Endocrinology, 85, 103. 